\title{
EFFECTS OF CHINESE EQUITY OWNERSHIP AND BOARD INVOLVEMENT ON FIRM PROFITABILITY: EVIDENCE FROM LISTED COMPANIES IN THE MALAYSIAN CONSTRUCTION SECTOR
}

\author{
Tee Peck-Ling ${ }^{1+}$ \\ Khin Aye-Aye ${ }^{2}$ \\ Raymond Ling \\ Leh-Bin $^{3}$ \\ Lim Boon-Keong ${ }^{4}$ \\ Salizatul Aizah \\ Ibrahim $^{5}$
}

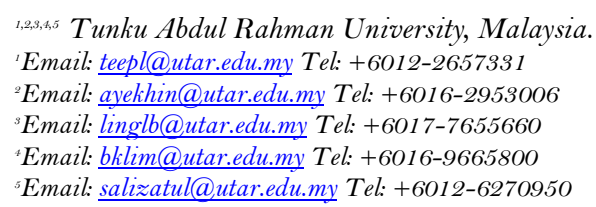

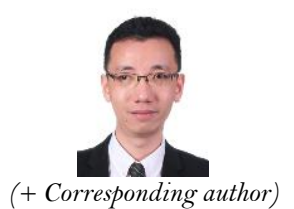

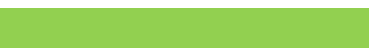

Article History

Received: 28 October 2021 Revised: 30 November 2021 Accepted: 15 December 2021 Published: 17 January 2022

\section{Keywords}

Chinese equity ownership

Chinese directors

Return on asset

Board diversity

Entrenchment

Construction sector.

JEL Classification: G30.
With 68 countries and international organizations signed up to and participating in the Belt and Road Initiative (BRI), the Chinese business community is playing an increasingly important role in the global economy. The number of Chinese-owned businesses within the top 50 of the Fortune Global 500 list has tripled from four in 2012 to 12 in 2017. With a sample of 24 out of the top 25 market capitalization Malaysian construction sector listed companies from 2012 to 2017, the random effects panel data regression model (REM) is applied. Results reveal that only the percentage of Chinese equity ownership (COWN) and the percentage of Chinese directors on corporate boards (CDIR) have significant relationships with companies' profitability measure of return on assets (ROA). Chinese CEOs (CCEO) can only improve a company's profitability after two years at the top of the management team. One of the main implications of this research is that COWN and CDIR should not be restricted by the government and indigenous protectionist groups because Chinese equity owners and directors can capitalize on their multi-lingual capabilities to build closer interpersonal ties and networking ("guanxi") with business partners from China and other BRI countries.

Contribution/Originality: This research is one of very few studies that has investigated how Chinese equity ownership and participation in the board of directors influence the profitability of Malaysian listed companies, in particular in the construction sector, which is one of the major contributors to Malaysia's Gross Domestic Product (GDP).

\section{INTRODUCTION}

China's government aims to champion globalization and free trade through its Belt and Road Initiative (BRI) by investing an enormous USD 1 trillion in infrastructure programs and financial institutions development, as well as enhancing the transportation (railways, highways and shipping ports) and telecommunication systems that could closely link Chinese businesses to Asian, Middle Eastern, European and African markets (Grant Thornton Singapore, 2018). With 68 countries involved in the Belt and Road Initiative, the Chinese business community is playing an increasingly important role in the global economy. The number of Chinese-owned businesses in the 
Fortune Global 500 list has been steadily increasing in recent years. As summarized in Table 1, although the number of Chinese-owned businesses within the top 10 remained the same, at three, from 2012 to 2017 , the number within the top 50 has tripled.

Table 1. Number of Chinese-owned businesses in the Fortune Global 500 list.

\begin{tabular}{c|c|c|c}
\hline Year & Top 10 & Top 25 & Top 50 \\
\hline 2012 & 3 & 3 & 4 \\
\hline 2013 & 3 & 3 & 6 \\
\hline 2014 & 3 & 4 & 7 \\
\hline 2015 & 3 & 4 & 8 \\
\hline 2016 & 3 & 6 & 11 \\
\hline
\end{tabular}

In addition, the contribution by Chinese businesses to the multi-ethnic Southeast Asia region is prominent and cannot be neglected. As compiled in Table 2 from the Forbes richest lists, the number of Chinese entrepreneurs within the top 20 richest Malaysian entrepreneurs has risen from 13 in 2012 to 16 in 2017. This is similar to Singapore percentage-wise at $80 \%$ (i.e., 16 out of 20), as corporate control by the Chinese varies between Malaysia and Singapore. Chinese equity ownership has been traditionally capped at $70 \%$ in Malaysia since the implementation of the 1971 New Economic Policy (NEP), which aimed to increase "bumiputera" (indigenous ethnic group) equity ownership to at least 30\%. On the contrary, there has been no restriction of Chinese equity ownership in Singapore since its independence. For both Malaysia and Singapore, the percentage of Chinese tycoons within their respective country's top 20 is higher than the rest of their Southeast Asian neighbors, for instance, only 11 out of 20 , or $55 \%$, in 2017 for the Philippines.

Table 2. Number of Chinese entrepreneurs in the Forbes List of Top 20 Richest among ASEAN countries.

\begin{tabular}{c|c|c|c}
\hline Year & Malaysia & Singapore & Philippines \\
\hline 2012 & 13 & 19 & 10 \\
\hline 2013 & 11 & 19 & 10 \\
\hline 2014 & 15 & 16 & 7 \\
\hline 2015 & 15 & 16 & 6 \\
\hline 2016 & 16 & 16 & 11 \\
\hline 2017 & 16 & 16 & 11 \\
\hline
\end{tabular}

Despite the cap, Chinese-owned firms in Malaysia continue to outperform their non-Chinese-owned counterparts. Nik Muhammad \& Md Isa (2009) attributed the success of Chinese-owned businesses to three possible reasons: (1) the Chinese community prefers family-run businesses which are likely to be more committed to bringing success and wealth to their family; (2) Chinese cultural value of Confucianism brings trust and reputation for business partners, suppliers and customers; and (3) the emphasis placed by Chinese families on knowledge learnt through education is eventually used in managing their businesses. Another study by Idris (2008) found that indigenous-owned businesses failed to keep pace with the growth and development of Chinese-owned businesses despite continuous assistance from the government.

Studies on how Chinese equity ownership influence firms' performance are still lacking in Malaysia, unlike research on the other types of ownership structure, such as state ownership (Mansor \& Lee, 2016) and foreign ownership (Tee, Lim, \& Aik, 2017). Moreover, most of the previous firm-level ownership studies only investigated how ownership affects firm performance but neglected the possibility that board involvement could also exert some influences, in particular when separation of ownership and control usually take place in many real-world corporations. The findings of Yeh, Lee, \& Woidtke (2001) revealed that Chinese entrepreneurs in Taiwan only need about $15 \%$ equity ownership to exert effective control over a public listed firm's decision making. The presence of 
Chinese directors on the board further indicates the importance of including board directorship in a firm's ownership structure study. Therefore, to provide some new empirical evidence and close these knowledge gaps, this research aims to examine the effects of both Chinese equity ownership and directorship together on firms' profitability among listed companies in the Malaysian construction sector. More specifically, research questions to be answered in this paper are: (i) Does Chinese equity ownership influence a company's profitability?; (ii) Does Chinese involvement in the board of directors add to board diversity and influence a company's profitability?; (iii) Does the election of a Chinese chairman to lead a company's board of directors influence its profitability?; (iv) Does the appointment of a Chinese Chief Executive Officer to lead a company's top management team influence its profitability?; and (v) Has controlling the stake of shareholdings by a Chinese individual or institution resulted in entrenchment that influences a company's profitability?

\section{LITERATURE REVIEW}

According to the resource-based view by Barney (1991), for a firm to achieve sustainable competitive advantage in the long run and generate above average profits, its bundle of resources has to be value-creating, rare, inimitable and non-substitutable by competitors (VRIN). In the current increasingly globalized business environment, a firm's access to valuable resources internationally (such as cheaper sources of financing, lower cost of skilled labor, larger customer base to exploit the benefits of economies of scale, reliable suppliers, and strategic business partners) could be enhanced through personal networks of its owners and directors. Therefore, local Chinese business owners and directors of Malaysian companies, who are able to communicate well in Mandarin and various Chinese dialects, can utilize their linguistic advantage to seek more business opportunities and gain access to VRIN resources, especially in China and Taiwan. From a resource-based view, it can be inferred that companies which have a higher percentage of Chinese equity ownership, a higher percentage of Chinese directors on the board, and are led by a Chinese chairman or managed by a Chinese CEO are more likely to have positive effects on a firm's profitability.

Additionally, the success of many Chinese-owned businesses could be attributable to the personality traits of their Chinese managers and Chinese cultural values. Sheh (2001) conducted interviews with several CEOs of Singapore listed companies under a longitudinal survey over a ten-year period from 1991 to 2000. The findings revealed that Chinese business leaders and top management team managers are more relationship-oriented ("guanxi”) rather than merely performance-oriented and emphasize more on employees' welfare compared to their counterparts from other ethnicities. Consequently, Chinese-owned firms are more able to retain high-performing staff and reduce the possibility of its staff being lured away by competitor companies. In addition, a study by Gu, Hung, \& Tse (2008) stated that "guanxi” is a valuable intangible asset (resource) that can enhance a firm's competence in managing challenges and developing responsive business strategies.

The upper echelons theory by Hambrick \& Mason (1984) explains that the choice of strategies and decisions for a firm are partially influenced by experiences, personalities, values and beliefs of the firm's individual top executives. On premise of the upper echelon theory, appointing more Chinese directors on the board of directors will bring in different values, experiences and cognitions to the decision-making process, which, in turn, can contribute to more creative and superior strategic solutions that positively affect the firm's performance. However, Williams \& O'Reilly III (1998) claimed that an increase in board diversity could bring group conflict that negatively influences a firm's performance. In Malaysia, Marimuthu \& Kolandaisamy (2009) found that gender and ethnic diversity among the board of directors (measured as the number of female or non-indigenous directors divided by total number of directors, respectively) had a partial positive effect on a firm's financial performance in 2003 only out of the overall sampling period from 2000 to 2006. However, in a further study by Marimuthu. (2010), ethnic diversity among the board of directors shows a significant positive relationship with financial performance.

Honing (2012) added in cultural distance within the board of directors when testing the relationship between a board's nationality diversity and company performance. Findings from German, British and Dutch MNCs revealed 
that when more foreigners are appointed to the executive boards, their stock market performance improves. However, when the number of different countries from which these foreign directors originated increases, cultural distance within the board increases and eventually worsens stock market performance. Although these findings show no support to the upper echelon theory, the situation in a multi-ethnic country like Malaysia is not similar. Indigenous and other ethnicities, owners and directors have long worked together with local Malaysian and Chinese owners and directors and understand each other's culture well. As a result, when Malaysian companies attract more Chinese investors or hire more Chinese directors from countries such as China, Taiwan, Korea, Hong Kong and Singapore, the cultural distance is likely to be narrow and hence unlikely to jeopardize a firm's performance.

According to the entrenchment theory, controlling shareholders and top management personnel of a company might try to make themselves irreplaceable by investing the company's resources in assets whose value will be higher under their management when compared to under other owners and managers, even though these selected investments do not maximize the company's value (Shleifer \& Vishny, 1989). In addition, Morel (2011) found that a manager who is also a controlling shareholder is likely to entrench and exploit the benefits of minority shareholders. Consequently, the incentive to maximize a firm's value declines. With the controlling voting rights, market forces of corporate takeover and management team replacement are no longer effective to discipline such non-value-maximizing behavior. Based on the entrenchment theory, having a Chinese controlling shareholder or a Chinese individual holding both the Chairman and CEO positions at the helm of the corporate hierarchy are likely to bring negative effects to a firm's profitability. Nevertheless, according to Haniffa \& Cooke (2002), although Chinese directors are more individualistic than indigenous directors, Chinese directors are more professional and secretive in contemplating business strategies that enhance the competitiveness and profitability of their firms.

\section{RESEARCH METHODOLOGY}

This paper examines the effects of Chinese equity ownership, the presence of Chinese directors on corporate boards, and the holding of Chairman and CEO positions by Chinese on the profitability of construction sector listed companies in Malaysia from 2012 to 2017. Based on the stock market capitalization of companies which are listed on Bursa Malaysia Stock Exchange's construction sector as of December 31, 2017, the top 25 ranked construction companies were eventually selected as the sample for this research. This research only focuses on the construction sector due to increasing collaboration between Malaysian and Chinese businesses in this sector in recent years. In one of the country's mega projects to build the Tun Razak Exchange (TRX), which aims to be the leading international finance and business centre, Chinese contractors have adopted and transferred their state-of-the-art technology that can speed up the construction process by building each floor of the TRX tower in just three days (Ho \& Yong, 2017). Moreover, in another mega project, Malaysia and China had also signed a RM55 billion contract to build the East Coast Rail Link (ECRL) in August 2017, with 85\% of the funding raised in the form of a loan from China's Export-Import Bank. In addition, PRG Holdings of Malaysia had also signed a collaboration agreement with Jiangsu Provincial Construction Group of China in October 2017. This RM5 billion collaboration will venture into the construction of highways, bridges and ports, as well as housing development. Furthermore, T7 Global Berhad had also formed a joint venture with one of the largest Chinese construction and real estate conglomerates in 2018, named as the T7 China Construction Third Engineering Sdn. Bhd. (T7CCTE), with the aim to bid for rail-related and other infrastructure development projects in Malaysia.

This study is solely based on secondary data. Financial statements and a list of the top 30 shareholders and directors' profiles were obtained from each sample company's annual reports. Annual reports were downloaded from Bursa Malaysia Stock Exchange's official website, and from the Bloomberg database if the data were not available from the former. 
A panel data model is adopted as the main research method in this study to test the relationships of ownership structure and governance structure variables with the profitability of listed companies in the Malaysian construction sector. It combines both cross-sectional $(\mathrm{N})$ and time series $(\mathrm{T})$ data. The panel data model is employed because it provides more informative data and enhances the efficiency of econometric estimates. A panel data model normally has a higher degree of freedom, and thus will lead to a more accurate inference of model parameters. Moreover, panel data model detects individual-specific effects, time effects or both in order to deal with any heterogeneity problems that might be observed (Gujarati \& Porter, 2009). The panel data regression model is stated as Equation 1 below:

$$
\mathrm{ROA}_{i t}=\beta_{0}+\beta_{1} \mathrm{COWN}_{\mathrm{it}}+\beta_{2} \mathrm{CDIR}_{\mathrm{it}}+\beta_{3} \mathrm{CCHM}_{\mathrm{it}}+\beta_{4} \mathrm{CCEO}_{\mathrm{it}}+\beta_{5} \mathrm{CCSH}_{\mathrm{it}}+\delta \mathrm{t}+\mu_{\mathrm{it}}
$$

where $\mu_{\mathrm{it}}=\alpha_{\mathrm{i}}+\varepsilon_{\mathrm{it}} ; \alpha_{\mathrm{i}}$ is the joint effects of the unobserved variable on firm profitability; $\varepsilon_{\mathrm{it}}$ it the error term; $\delta$ is the shift of intercept over time; i denotes each individual construction company in Malaysia; and t denotes each financial reporting year from 2012 to 2017. Variables in Equation 1 are defined as follows:

(i) Return on Assets (ROA) is net income divided by total assets, where net income is earnings after tax minus preference share dividends (if any).

(ii) Percentage of Chinese equity ownership (COWN) is the sum of ordinary shares owned by Chinese individuals and institutions obtained from the annual report's list of top 30 shareholders divided by total number of ordinary shares outstanding of the selected sample company. The term "Chinese" does not just include ethnic and descendant Chinese from their home country (Malaysia), but also indigenous Chinese from the People's Republic of China as well as ethnic Chinese from other countries. Shah et al. (2010) have tested the validity of using a list of surnames to distinguish whether an individual shareholder is Chinese or non-Chinese from various secondary data sources.

(iii) Percentage of Chinese directors (CDIR) is the number of Chinese directors divided by the total number of directors sitting on the selected sample company's board of directors. This measure is borrowed from Marimuthu \& Kolandaisamy (2009) and Tee et al. (2017), whose studies measured the percentage of non-indigenous directors and foreign directors, respectively. Again, the method used by Shah et al. (2010) is used to determine whether a director is Chinese or non-Chinese from the annual reports' directors' profiles.

(iv) Chinese Chairman dummy (CCHM) takes a value of "1" if the company's Chairman is Chinese, and "O" otherwise.

(v) Chinese Chief Executive Officer dummy (CCEO) takes a value of "1" if the company's CEO is Chinese, and "O" otherwise.

(vi) Chinese controlling shareholder dummy (CCSH) takes a value of "1" if the company's largest shareholder is Chinese, and "O" otherwise.

ROA is set as the dependent variable in this regression model, while the independent variables include COWN, CDIR, CCHM, CCEO and CCSH. In terms of the measurement scale, ROA, COWN and CDIR are computed in percentages, while CCHM, CCEO and CCSH are dummy variables. These data were collected annually from 2012 to 2017. Due to data availability, 24 out of the top 25 listed companies in the Malaysian construction sector ranked by market capitalization with a total of 135 firm-year observations were eventually included for data analysis in this research. Since the number of years $(T=6)$ is relatively smaller than the number of selected sample companies $(\mathrm{N}=$ 24), this dataset can be considered as a micro panel, which is also known as a longitude panel. The above panel data regression model will be run on an unbalanced panel of 135 firm-year observations to test the following hypotheses:

H1: There is a relationship between the percentage of Chinese equity owners (COWN) and a company's profitability measure of return on assets $(R O A)$.

H2: There is a relationship between the percentage of Chinese directors (CDIR) and a company's profitability measure of return on assets $(R O A)$. 
H3: The elected Chinese Chairman (CCHM) affects a company's profitability measure of return on assets (ROA).

H4: The appointed Chinese CEO (CCEO) affects a company's profitability measure of return on assets (ROA).

H5: Chinese controlling shareholders (CCSH) affect a company's profitability measure of return on assets (ROA).

The resource-based view predicts significant positive relationships for $\mathrm{H} 1$ to $\mathrm{H} 4$. The upper echelons theory also predicts a significant positive relationship for H2. On the other hand, the entrenchment theory predicts a significant negative relationship for $\mathrm{H} 5$.

Panel unit root testing arises from time series unit root testing. The major difference between these two types of unit root testing is the asymptotic behavior of the time series dimension $\mathrm{T}$ and the cross-sectional dimension $\mathrm{N}$ (Verbeek, 2008). Levin, Lin, \& Chu (2002) proposed a unit root test with the following test hypotheses:

$H_{0}$ : Each panel data contains a unit root (not stationary).

$H_{A:}$ Each panel data does not contain a unit root (Stationary).

On the other hand, Im, Pesaran, \& Shin (2003) proposed another unit root test which is not as restrictive as the Levin et al. (2002) test. It tolerates individual effects or heterogeneous coefficients. It also allows the more general alternative that it can vary and that some individuals can have a unit root. The test hypotheses are as follows:

$H_{0}:$ Each panel data is non-stationary.

$H_{A}$ : At least one of the panel data is stationary.

Assuming the model in this study is a static model, three types of panel data regression model can be analyzed, namely pooled ordinary least squares (POLS), fixed effects model (FEM), and random effects model (REM). If there is no individual effect in the model, a normal OLS will produce efficient and consistent estimates of the parameters. However, the model could be a FEM or a REM if individual effects exist (Fong, Khin, \& Lim, 2018). There are three tests to be conducted to select an appropriate model for data analysis. A redundant fixed effects test will select between the POLS and FEM, the Breusch-Pagan Lagrange Multiplier (BPLM) test will select between the POLS and REM, while the Hausman test (Hausman, 1978) will choose between the FEM and REM. After the most appropriate model is determined, a regression analysis will be conducted. Robustness checking will be done after the regression analysis in order to avoid misleading inferences, including diagnosis of residuals, multicollinearity analysis and autocorrelation analysis.

Furthermore, a panel cointegration test will be conducted to check whether there is any long-run equilibrium relationship between variables in the model. Two types of panel cointegration test will be employed, namely the Pedroni test (Pedroni, 2004) and the Kao test (Kao, 1999). Hypotheses of the cointegration test are as follows:

$H_{0:}$ There is no cointegration in the series.

$H_{A}$ : There is cointegration in the series.

Both of these tests extended the Engle-Granger framework to test cointegration on the panel data. The Kao test of cointegration (Kao, 1999) is for homogeneous panel data. Kao test statistics are calculated by pooling all the residuals of all cross-sections in the panel, and it assumes that all the cointegrating vectors in every cross-section are equal. On the other hand, Pedroni proposed several tests for panel cointegration, which allow for considerable heterogeneity (Narayan, Narayan, \& Prasad, 2008).

Furthermore, a Granger causality test will also be carried out to examine the directional causal relationship among variables in the company's profitability model of this study. $\mathrm{X}$ is said to Granger-cause $\mathrm{Y}$ if the prediction of $\mathrm{Y}$ improves when the previous values of $\mathrm{X}$ are taken into account (Studenmund, 2014). Hypotheses of the Granger causality test are as follows:

$H_{0}: X$ does not Granger-cause $Y$.

$H_{A}: X$ Granger-causes $Y$.

On top of that, a Granger causality test for panel data analysis is more accurate than those based on individual time series only. It will also show the unidirectional or bidirectional causality effects that exist in the model. 
According to the Classical Linear Regression Model (CLRM), one of the assumptions stated is that the error term has no multicollinearity in a regression model. If it has, it means that a number of independent variables in a multiple regression model are closely correlated with each other. This is an unwanted situation in a regression analysis, as it can lead to misleading results, wider confidence intervals, and less reliable probability values ( $p$-values) for the exogenous variables (Gujarati \& Porter, 2009; Studenmund, 2014). The variance inflation factor (VIF) and tolerance (TOL) are used to detect the presence of multicollinearity problems in a regression model. Mathematically, TOL is the reciprocal of VIF:

$$
V I F=\frac{1}{1-R^{2}} \quad \text { or } \quad \text { TOL } \frac{=1}{V I F}
$$

A larger value of VIF signals a higher possibility of the existence of multicollinearity. Hypotheses of multicollinearity test are as follows:

\section{$H_{0:}$ The error term has no multicollinearity.}

\section{$H_{4}$ The error term has multicollinearity.}

When the calculated VIF value exceeds 5 or the TOL value falls below 0.2, this null hypothesis is rejected, which means there is multicollinearity between independent variables in the model. When the VIF value is lower than 5 or the TOL value is higher than 0.2 , then this null hypothesis will not be rejected, which indicates there is no multicollinearity issue.

Autocorrelation, or serial correlation, represents the degree of similarity between a given time series value and a lagged version of itself over successive time intervals (Studenmund, 2014). Pure serial correlation occurs when the assumption of uncorrelated observations of the error term is violated in a correctly specified equation. If the expected value of the simple correlation coefficient between any two observations of the error term is not equal to zero, then the error term is said to be serially correlated. Serial correlation can cause the estimators of the standard error to be biased and lead to unreliable hypothesis testing (Studenmund, 2014). The Durbin-Watson test (d) is used as the test statistic to detect the existence of serial autocorrelation (AC) between the residuals from a regression. The formula for $\mathrm{AC}$ is 1-(d/2). Hypotheses of the serial autocorrelation test are as follows:

$H_{0}$ : The error term is not serially autocorrelated.

\section{$H_{A}$ The error term is serially autocorrelated.}

Guildford's rule of thumb indicates the strength of serial autocorrelation (AC), as listed in Table 3. If the value of $\mathrm{AC}$ is less than 0.2 , or between 0.2 and 0.4 , then the null hypothesis will not be rejected and indicates that serial autocorrelation does not exist.

Table 3. Strength of Serial Autocorrelation.

\begin{tabular}{l|l}
\hline Range of Serial Autocorrelation Values & Description \\
\hline Less than 0.2 & Almost negligible \\
\hline 0.2 to 0.4 & Low \\
\hline O.4 to 0.7 & Moderate \\
\hline O.7 to 0.9 & High \\
\hline More than 0.9 & Very high \\
\hline Source: Studenmund (2014).
\end{tabular}

\section{RESULTS AND DISCUSSION}

\subsection{Descriptive Analysis}

Table 4 summarizes the descriptive statistics of variables in this study. The mean percentage of Chinese equity ownership (COWN) among listed companies in the Malaysian construction sector has gradually decreased from its peak of $34.26 \%$ in 2013 to $24.39 \%$ in 2017 and averaged at $29.12 \%$ over the six-year period. In contrast, the mean percentage of Chinese directors on construction companies' boards (CDIR) is significantly higher than the COWN 
mean. The CDIR mean steadily increased from $60.59 \%$ in 2012 to $61.33 \%$ in 2017 and averaged at $61.22 \%$ over the six-year period. A lower COWN mean in comparison to the CDIR mean could be possibly due to the 1971 New Economic Policy, which aimed to increase indigenous equity ownership and, in turn, indirectly restricted Chinese equity ownership.

Table 4. Mean percentages of Chinese equity ownership (COWN) and Chinese directors (CDIR), and the prevalence of Chinese Chairmen (CCHM), Chinese Chief Executive Officers (CCEO) and Chinese controlling shareholders (CCSH) in the listed companies in the Malaysian construction sector

\begin{tabular}{|c|c|c|c|c|c|}
\hline & \multicolumn{2}{|c|}{ Mean Percentage (\%) } & \multicolumn{3}{|c|}{ Frequency Count (number of companies) } \\
\hline Year & COWN & CDIR & CCHM & CCEO & $\mathrm{CCSH}$ \\
\hline 2012 & $32.07 \%$ & $60.59 \%$ & 5 & 18 & 8 \\
\hline 2013 & $34.26 \%$ & $61.15 \%$ & 5 & 18 & 6 \\
\hline 2014 & $30.69 \%$ & $61.30 \%$ & 5 & 20 & 8 \\
\hline 2015 & $31.63 \%$ & $61.68 \%$ & 7 & 20 & 9 \\
\hline 2016 & $27.22 \%$ & $61.21 \%$ & 7 & 20 & 7 \\
\hline 2017 & $24.39 \%$ & $61.33 \%$ & 7 & 19 & 7 \\
\hline Average & $29.12 \%$ & $61.22 \%$ & 6 & 19.17 & 7.50 \\
\hline
\end{tabular}

Moreover, Table 4 also shows that only six out of the 24 companies on average have elected a Chinese individual to hold the Chairman (CCHM) position. This is unsurprising given that the election of the chairman is based on shareholders' voting rights. Since the COWN mean averaged at $29.12 \%$, and only 7.5 out of the 24 companies on average have a Chinese controlling shareholder, Chinese owners are lacking dominant voting rights and influences to elect a Chinese chairman to lead their respective company's board. In contrast, 19.17 out of the 24 companies on average have appointed a Chinese CEO (CCEO) to lead their respective company's top management team. The appointment of a CEO is usually based on the board of directors' recommendation rather than owners' voting rights, hence the cap on COWN does not restrict the appointment of a CCEO.

\subsection{Panel Unit Root Tests}

Table 5 summarizes the results of the unit root tests of the model. Two types of unit root test are conducted, namely the Levin et al. (2002) test and Im et al. (2003) test. Since CCHM, CCEO and CCSH are all dummy variables where the values are either " 1 " or "O", only the dependent variable ROA and two of the independent variables (COWN and CDIR) are tested for stationarity. The results from the Levin et al. (2002) test indicate that only ROA and COWN are stationary at level but CDIR is not. All the variables are only stationary at Ln and $1^{\text {st }}$ difference data. Therefore, the null hypothesis is rejected at $\alpha=0.05$ and 0.01 levels. Also, the Im et al. (2003) test showed that ROA is the only variable that is stationary in level and Ln data. After first difference, only ROA and COWN are stationary. Therefore, for ROA and COWN, the null hypothesis is rejected at the $\alpha=0.01$ level. However, for CDIR, the null hypothesis is not rejected.

Table 5. Panel Unit Root Test Results.

\begin{tabular}{c|c|c|c|c|c|c|}
\hline \multirow{2}{*}{} & \multicolumn{3}{|c|}{ Levin, Lin \& Chu } & \multicolumn{3}{c}{ Im, Pesaran \& Shin } \\
\cline { 2 - 7 } & Level & Ln & $\mathbf{1}^{\text {st }} \mathbf{d i f f}$ & Level & Ln & $\mathbf{1}^{\text {st }} \mathbf{d i f f}$ \\
\hline$R O A$ & $-14.7043^{* * *}$ & $-11.8466^{* * * *}$ & $-16.3348^{* * *}$ & $-3.8396^{* * *}$ & $-3.7293^{* * *}$ & $-5.8931^{* * *}$ \\
\hline$C O W N$ & $-4.3830^{* * *}$ & $-2.5346^{* * *}$ & $-15.3434^{* * *}$ & -0.0486 & 0.1714 & $-5.5702^{* * *}$ \\
\hline$C D I R$ & -0.8389 & $-1.9074^{* *}$ & $-1.7401^{* *}$ & 1.3701 & 0.8428 & -0.2691 \\
\hline
\end{tabular}

\subsection{Panel Model Selection Tests}

Referring to Table 6, three tests are performed to select the most appropriate model for the panel data regression analysis. Results of the redundant fixed effects test show that the p-value is equal to 0.0000, which rejects the null hypothesis. The fixed effects model is then preferred over the pooled OLS. The results of the Breusch-Pagan LM test show that the p-value is equal to 0.0001 , which also rejects the null hypothesis. The 
random effects model is then preferred over the pooled OLS. Eventually, the Hausman test is performed and its results reveal that the p-value is equal to 0.2426, which means that the null hypothesis is not rejected and the random effects model is then preferred over the fixed effects model. Conclusively, the random effects model is the most appropriate for panel data regression analysis in this research.

Table 6. Panel Models Selection Test Results.

\begin{tabular}{l|l|l|l}
\hline Test & Hypothesis & P-value & Decision Rule \\
\hline $\begin{array}{l}\text { Redundant Fixed Effects } \\
\text { Test }\end{array}$ & $\begin{array}{l}\mathrm{H}_{\mathrm{O}}=\mathrm{POLS} \text { is preferable } \\
\mathrm{H}_{\mathrm{A}}=\mathrm{FEM} \text { is preferable }\end{array}$ & $0.0000<\alpha=0.05$ & $\begin{array}{l}\text { Reject } \mathrm{H}_{0}, \mathrm{FEM} \text { is } \\
\text { preferable. }\end{array}$ \\
\hline Breusch-Pagan LM Test & $\begin{array}{l}\mathrm{H}_{\mathrm{O}}=\mathrm{POLS} \text { is preferable } \\
\mathrm{H}_{\mathrm{A}}=\mathrm{REM} \text { is preferable }\end{array}$ & $0.0001<\alpha=0.05$ & $\begin{array}{l}\text { Reject } \mathrm{H}_{0}, \mathrm{REM}_{\text {is }} \\
\text { preferable. }\end{array}$ \\
\hline Hausman Test & $\begin{array}{l}\mathrm{H}_{\mathrm{O}}=\mathrm{REM} \text { is preferable } \\
\mathrm{H}_{\mathrm{A}}=\mathrm{FEM} \text { is preferable }\end{array}$ & $0.2426>\alpha=0.05$ & $\begin{array}{l}\text { Do not reject } \mathrm{H}_{\mathrm{O}}, \mathrm{REM}_{\text {is }} \\
\text { preferable. }\end{array}$ \\
\hline
\end{tabular}

\subsection{Random Effects Model (REM) Regression Analysis}

Results of the REM regression are illustrated in Table 7, and the REM equation that has been checked for robustness is constructed in Equation 2. As mentioned in the previous section, testing the residuals diagnosis could remedy the problems of multicollinearity and serial autocorrelation and thus avoid any misleading inferences. Therefore, the final regression equation is stated as follows:

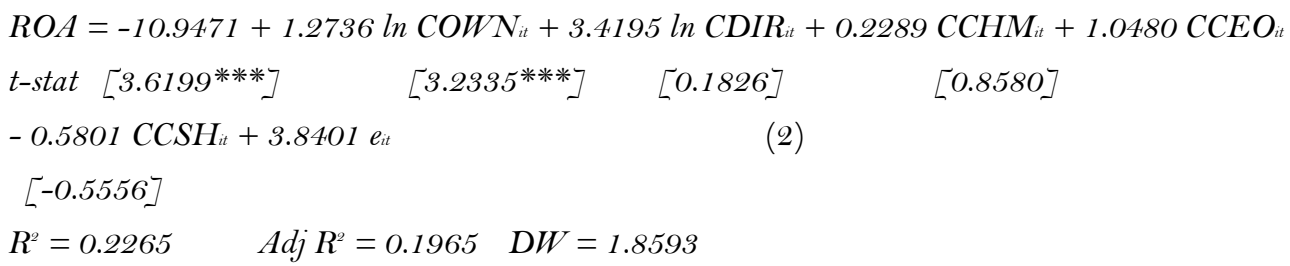

Table 7. Random Effects Model (REM) Regression Results.

\begin{tabular}{l|c|c|c|c}
\hline Dependent Variable: ROA & Coefficient & Std. Error & t-Statistic & Prob. \\
\hline Variable & $1.273755^{* * *}$ & 0.351879 & 3.619865 & 0.0004 \\
\hline LNCOWN & $3.419544^{* * *}$ & 1.057535 & 3.233504 & 0.0016 \\
\hline LNCDIR & 0.228914 & 1.252552 & 0.182758 & 0.8553 \\
\hline CCHM & 1.048043 & 1.221363 & 0.858093 & 0.3924 \\
\hline CCEO & -0.580080 & 1.043982 & -0.555642 & 0.5794 \\
\hline CCSH & -10.94713 & 3.840907 & -2.850142 & 0.0051 \\
\hline C & Weighted Statistics & & \\
\hline R-squared & 0.226502 & Mean dependent variable & 0.841183 \\
\hline Adjusted R-squared & 0.196522 & S.D. dependent variable & 1.108177 \\
\hline Std. error of regression & 0.961840 & Sum squared residual & 119.3425 \\
\hline F-statistic & 7.554977 & Durbin-Watson statistic & 1.859347 \\
\hline Prob(F-statistic) & 0.000003 & & \\
\hline Note: ***, ** and * denote that the coefficient is significant at the 0.01, 0.05 and 0.10 levels, respectively.
\end{tabular}

The REM regression indicates that $\mathrm{R}^{2}$ equals 0.2265 , which means that almost $22.65 \%$ of the variations in the model are well explained by the explanatory variables. COWN and CDIR are the most significant variables in the model with the highest coefficient and t-statistic values. Therefore, every $1 \%$ increase in the percentage of Chinese equity ownership (COWN) in a company will on average have a positive effect of raising the company's ROA by $1.2736 \%$, holding other variables constant. Similarly, every $1 \%$ increase in the percentage of Chinese directors (CDIR) sitting on a company's board will on average have a positive effect of improving the company's ROA by $3.4195 \%$, holding other variables constant. Both COWN and CDIR are statistically strongly significant at the $\alpha=$ 0.01 level. Nevertheless, Chinese chairmen (CCHM), Chinese CEOs (CCEO) and Chinese controlling shareholders $(\mathrm{CCSH})$ are all insignificant in affecting a company's ROA, even at the $\alpha=0.10$ level. 
Table 8. Panel Cointegration Test Results.

\begin{tabular}{l|c|c|c}
\hline Pedroni Test & \multicolumn{2}{c}{ Kao Test } \\
\hline Panel v-Statistic & -1.0737 & ADF & $-3.3843^{*} * *$ \\
\hline Panel rho-Statistic & 1.9347 & & \\
\hline Panel PP-Statistic & $-4.4413^{*} * *$ & & \\
\hline Panel ADF-Statistic & $-3.2014^{* * *}$ & & \\
\hline Group rho-Statistic & 3.6386 & & \\
\hline Group PP-Statistic & $-4.7426^{*} * *$ & & \\
\hline Group ADF-Statistic & $-3.6281^{*} * *$ & & \\
\hline Note: ***, ** and * denote that the test statistic is significant at the $0.01,0.05$ and 0.10 levels, respectively.
\end{tabular}

Table 9. Granger Causality Tests (summary of results).

\begin{tabular}{|c|c|c|c|c|c|}
\hline Alternative Hypothesis $\left(\mathbf{H}_{\mathrm{A}}\right)$ & Lag & Obs. & F-statistic & Prob. & $\mathrm{H}_{\mathrm{A}}$ Supported or Rejected? \\
\hline LNCOWN Granger-causes ROA & 2 & \multirow{2}{*}{89} & $5.65109^{* * * *}$ & 0.0050 & Supported \\
\hline ROA Granger-causes LNCOWN & & & 0.49293 & 0.6126 & Rejected \\
\hline CCEO Granger-causes ROA & 2 & \multirow{2}{*}{94} & $2.81184^{*}$ & 0.0654 & Supported \\
\hline ROA Granger-causes CCEO & & & 0.42647 & 0.6541 & Rejected \\
\hline CCHM Granger-causes LNCOWN & 2 & \multirow{2}{*}{89} & 1.54363 & 0.2196 & Rejected \\
\hline LNCOWN Granger-causes CCHM & & & $3.09982^{*}$ & 0.0502 & Supported \\
\hline CCSH Granger-causes LNCDIR & 2 & \multirow{2}{*}{90} & $4.71410^{* *}$ & 0.0114 & Supported \\
\hline LNCDIR Granger-causes CCSH & & & 0.23533 & 0.7908 & Rejected \\
\hline CCSH Granger-causes CCEO & 2 & \multirow{2}{*}{94} & 1.57868 & 0.2120 & Rejected \\
\hline CCEO Granger-causes CCSH & & & $8.50506^{* * * *}$ & 0.0004 & Supported \\
\hline
\end{tabular}

Table 10. Granger Causality Tests (detailed output)

\begin{tabular}{|c|c|c|c|}
\hline Null Hypothesis: & Obs. & F-statistic & Prob. \\
\hline LNX1 does not Granger-cause Y1 & 89 & $5.65109^{*} * *$ & 0.0050 \\
\hline \multicolumn{2}{|l|}{ Y1 does not Granger-cause LNX1 } & 0.49293 & 0.6126 \\
\hline LNX2 does not Granger-cause Y1 & 90 & 1.14929 & 0.3217 \\
\hline \multicolumn{2}{|l|}{ Y1 does not Granger-cause LNX2 } & 0.15396 & 0.8575 \\
\hline X3 does not Granger-cause Y 1 & 94 & 0.91686 & 0.4035 \\
\hline \multicolumn{2}{|l|}{ Y1 does not Granger-cause X3 } & 0.06008 & 0.9417 \\
\hline X4 does not Granger-cause Y 1 & 94 & $2.81184^{*}$ & 0.0654 \\
\hline \multicolumn{2}{|l|}{ Y1 does not Granger-cause X4 } & 0.42647 & 0.6541 \\
\hline X5 does not Granger-cause Y 1 & 94 & 1.75070 & 0.1796 \\
\hline \multicolumn{2}{|l|}{ Y1 does not Granger-cause X5 } & 1.09756 & 0.3382 \\
\hline LNX2 does not Granger-cause LNX1 & 85 & 0.04143 & 0.9594 \\
\hline \multicolumn{2}{|l|}{ LNX1 does not Granger-cause LNX2 } & 0.16657 & 0.8469 \\
\hline X3 does not Granger-cause LNX1 & 89 & 1.54363 & 0.2196 \\
\hline \multicolumn{2}{|l|}{ LNX1 does not Granger-cause X3 } & $3.09982^{*}$ & 0.0502 \\
\hline X4 does not Granger-cause LNX1 & 89 & 0.55007 & 0.5790 \\
\hline \multicolumn{2}{|l|}{ LNX1 does not Granger-cause X4 } & 1.92865 & 0.1517 \\
\hline X5 does not Granger-cause LNX1 & 89 & 1.63166 & 0.2017 \\
\hline \multicolumn{2}{|l|}{ LNX1 does not Granger-cause X5 } & 0.47154 & 0.6257 \\
\hline X3 does not Granger-cause LNX2 & 90 & 0.53771 & 0.5861 \\
\hline \multicolumn{2}{|l|}{ LNX2 does not Granger-cause X3 } & 0.67620 & 0.5113 \\
\hline X4 does not Granger-cause LNX2 & 90 & 0.60679 & 0.5474 \\
\hline \multicolumn{2}{|l|}{ LNX2 does not Granger-cause X4 } & 2.25916 & 0.1107 \\
\hline X5 does not Granger-cause LNX2 & 90 & $4.71410^{* *}$ & 0.0114 \\
\hline \multicolumn{2}{|l|}{ LNX2 does not Granger-cause X5 } & 0.23533 & 0.7908 \\
\hline X4 does not Granger-cause X3 & 94 & 0.22538 & 0.7987 \\
\hline \multicolumn{2}{|l|}{ X3 does not Granger-cause X4 } & 0.37113 & 0.6910 \\
\hline X5 does not Granger-cause X3 & 94 & 0.16901 & 0.8448 \\
\hline \multicolumn{2}{|l|}{ X3 does not Granger-cause X5 } & 0.41288 & 0.6630 \\
\hline X5 does not Granger-cause X4 & 94 & 1.57868 & 0.2120 \\
\hline \multicolumn{2}{|l|}{ X4 does not Granger-cause X5 } & $8.50506^{* * * *}$ & 0.0004 \\
\hline
\end{tabular}




\subsection{Panel Cointegration Tests}

Table 8 summarizes the results of the panel cointegration tests of the model. The Pedroni panel cointegration test results reveal that four out of the seven statistics, namely Panel PP-Statistic, Panel ADF-Statistic, Group PPStatistic and Group ADF-Statistic, are significant. Therefore, the null hypothesis can be rejected at the $\alpha=0.01$ level, which suggests that there is cointegration among the variables in the model. Moreover, Kao (1999) carried out a cointegration test that generated a t-statistic of -3.3843, which is also significant at the $\alpha=0.01$ level. This confirms the evidence of cointegration in the model as the null hypothesis is again rejected.

\subsection{Granger Causality Tests}

Table 9 shows the summary of the Granger causality test results for the model. The results indicate that there are five unidirectional causal relationships running in the model, which are: (1) the percentage of Chinese equity ownership (COWN) Granger-caused ROA at the $\alpha=0.01$ level; (2) Chinese CEOs (CCEO) Granger-caused ROA at the $\alpha=0.10$ level; (3) the percentage of Chinese equity ownership (COWN) Granger-caused Chinese chairmen (CCHM) at the $\alpha=0.10$ level; (4) Chinese controlling shareholders (CCSH) Granger-caused a percentage of Chinese directors (CDIR) at the $\alpha=0.05$ level; and (5) Chinese CEOs (CCEO) Granger-caused Chinese controlling shareholders $(\mathrm{CCSH})$ at the $\alpha=0.01$ level. In short, these alternative hypotheses of causal relationship presence are being supported. There is statistically significant evidence that points out Xs (COWN and CCEO) Granger-caused $\mathrm{Y}$ (ROA), but there is no significant evidence to indicate that Y Granger-caused any of the Xs. The detailed Granger causality test outputs are shown in Table 10.

\subsection{Residual Diagnosis - Multicollinearity Test}

The REM shows that the $\mathrm{R}^{2}$ value is 0.2262 , therefore: $V I F=1 /\left(1-R^{2}\right)=1 /(1-0.2262)=1.2923<5$

Since the VIF is less than 5, the null hypothesis is not rejected. This indicates that there is no existence of a multicollinearity problem in the research model, as stated in Equation 2.

\subsection{Residual Diagnosis - Serial Autocorrelation Test}

The REM generates a Durbin-Watson (DW) value of 1.8593, therefore: $A C=1-(d / 2)=1-(1.8593 / 2)=0.0704$

Since the AC value is less than 0.2, there is an almost negligible level of serial autocorrelation in the model. The null hypothesis is not rejected, which indicates that there is no serial autocorrelation problem.

\section{CONCLUSION}

Based on the results from REM panel data regression, there is statistically significant evidence to reject the null hypothesis and accept the alternative hypothesis for $\mathrm{H} 1$ (there is a relationship between the percentage of Chinese equity ownership (COWN) and a company's profitability measure of return on assets (ROA)) and H2 (there is a relationship between the percentage of Chinese directors (CDIR) and a company's profitability measure of return on assets (ROA)). The positive coefficients of COWN and CDIR indicate that both of these variables have a significant positive relationship with ROA. These findings support the resource-based theory. Chinese owners, especially those from the People's Republic of China, possess huge capital resources and other VRIN resources. Therefore, the Malaysian government and some non-government organizations which protect the rights of indigenous ethnic groups in Malaysia should be more open-minded and stop restricting Chinese equity ownership directly or indirectly. An increase in COWN has proven to bring improvement to the profitability of Malaysian construction companies, and such elevated performance allows companies to expand their businesses and create more job opportunities. Rising job opportunities can, in turn, increase the income level of all employees, especially 
those from indigenous ethnic groups. In that way, the issue of income inequality between indigenous and other ethnic groups can be mitigated. Furthermore, the mean COWN that averaged at $29.12 \%$ over the period from 2012 to 2017 is still some $20.88 \%$ below the $50 \%$ mark of being the controlling shareholder of a company. Even if the government and indigenous protectionist organizations still want indigenous ethnic groups to remain as the controlling shareholders, there is no harm in letting Chinese shareholders raise their equity stake by up to an extra $20 \%$. The REM regression results have shown that every $1 \%$ increase in COWN will elevate ROA by $1.2736 \%$. Moreover, if Malaysian construction companies can attract more Chinese investors from the People's Republic of China to collaborate or invest in their companies, superior and state-of-the-art technology in construction can be transferred to Malaysia as witnessed in some of the collaborations between Malaysia and China in various construction projects carried out thus far. Technology transfers can help to increase operating efficiency, reduce costs, and improve bottom line profits.

A significant positive relationship between CDIR and ROA supports the upper echelons theory. Therefore, the new government of Malaysia should continue to step up the effort to unite all ethnicities and increase understanding and acceptance of other ethnicities' cultural backgrounds, values and practices in order to reduce the possibility of conflict and lack of communication among directors sitting on ethnically-diverse boards, which can negatively affect a company's performance. Construction companies in Malaysia should maintain the current level of ethnic diversity on the board and not necessarily have to increase the percentage of Chinese directors on corporate boards because the mean CDIR that averaged at $61.22 \%$ during the period from 2012 to 2017 is already sufficient, and a further increase in CDIR might actually reduce the level of board diversity. Instead of raising CDIR, construction companies in Malaysia should perhaps only appoint foreign Chinese directors or local Chinese directors who have vast international experience. Through sharing their exposure and experience in the international business arena, these Chinese directors can provide more valuable and creative ideas and subsequently bring strategic changes that will enhance a company's profitability. With the upgrade of the China-Malaysia bilateral economic cooperation status to a comprehensive strategic partnership since 2015, having more local or foreign Chinese directors on corporate boards who understand Chinese business culture and are able to communicate more effectively in Mandarin, various Chinese dialects and other languages could help their companies build and secure closer relationship with business partners from China as well as other countries participating in the Belt and Road Initiative. This recommendation is in line with Minai, Ibrahim, \& Kheng (2012), whose study found that Chinese entrepreneurs and executives utilize their interpersonal ties and networking ("guanxi"), which are important elements in Chinese business practices, to gain access to valuable resources and new business opportunities that could enhance business growth and contribute to higher earnings.

Given that both the COWN and CDIR positively affect a company's profitability, portfolio investors can consider reshuffling their investment portfolios to include stocks of some listed companies in the Malaysian construction sector which have higher COWN and CDIR. With the global economic and business environments become increasingly uncertain and challenging arising from the international trade war between two of the world's largest economies, the United States and the People's Republic of China, companies owned by Chinese or managed by Chinese directors are likely to perform better. Sheh (2001) pointed out that Chinese directors are more able to withstand hardship, work under tough and challenging conditions, and manage various types of risk which their companies are exposed to. Although the results from the REM regression do not reject the null hypothesis of $\mathrm{H} 4$ (the appointed Chinese CEO (CCEO) affects a company's profitability measure of return on assets (ROA)), the results from the Granger causality test do. CCEO has a positive causal relationship with a company's ROA after lagged for two periods. This means that when a Chinese CEO has been appointed to direct the company's top management team, he needs about two years to significantly improve the company's bottom line instead of boosting the company's profits instantaneously or in a short period of time. Therefore, business owners who appoint a Chinese CEO should be more patient and give the chosen CEO sufficient time to implement effective changes that 
can increase the company's earnings. Furthermore, the results from the REM regression analysis failed to reject the null hypothesis of $\mathrm{H} 3$ (the elected Chinese chairman (CCHM) affects a company's profitability measure of return on assets (ROA)). This is probably due to the fact that the mean COWN among the Malaysian construction sector listed companies only averaged at $29.12 \%$ over the 2012-2017 period and are thus unlikely to have enough voting rights to elect their most preferred and qualified Chinese candidate for the position of Chairman. In addition, the null hypothesis of H5 (Chinese controlling shareholder (CCSH) affects a company's profitability measure of return on assets (ROA)) was also not rejected. This is probably associated with the fact that the preceding Malaysian government had been practicing nepotism by granting lucrative construction projects to construction companies owned and controlled by their indigenous relatives and friends rather than through fair open biddings. Such unethical nepotism practices perhaps explain why companies with a Chinese controlling shareholder (CCSH) are not significantly more profitable than their competitors with an indigenous controlling shareholder. Consequently, this practice also curtails Chinese investors to increase their equity stakes in a particular Malaysian construction company up to the controlling shareholding level. As shown in Table 4, only 7.5 companies out of the top 25 market capitalization construction sector listed companies in Malaysia on average have a CCSH.

Although the null hypothesis of $\mathrm{H} 5$ is not rejected, two unidirectional causal relationships identified from Granger causality tests revealed some evidence to support the entrenchment theory. First, CCSH is found to Granger-cause CDIR. This implies that a CCSH can entrench by using his dominant voting rights to elect as many Chinese candidates as possible for whom he has a preference or to whom he is closely related to sit on the board of directors. In that way, whatever strategic decisions the CCSH wanted to push through can be easily approved by the board without many obstacles. Second, CCEOs are found to Granger-cause CCSH. This implies that a CCEO can entrench by starting to increase and accumulate his equity shareholding in the company until it reaches a controlling stake and become the CCSH. If that happens, his CEO position is likely to be unchallenged.

Funding: This study received no specific financial support.

Competing Interests: The authors declare that they have no competing interests.

Authors' Contributions: All authors contributed equally to the conception and design of the study.

\section{REFERENCES}

Barney, J. (1991). Firm resources and sustained competitive advantage. Journal of Management, 17(1), 99-120. Available at: https://doi.org/10.1177/014920639101700108.

Fong, Y. C., Khin, A. A., \& Lim, C. S. (2018). Conceptual review and the production, consumption and price models of the natural rubber industry in selected ASEAN countries and world market. Asian Journal of Economic Modelling, 6(4), 403-418. Available at: https://doi.org/10.18488/journal.8.2018.64.403.418.

Grant Thornton Singapore. (2018). Belt and road road opportunities. Retrieved from: https://www.grantthornton.sg/insights/the-road-to-prosperity-infrastructure-improvements-driving-asean-businessoutlook/. [Accessed December 20, 2021].

Gu, F. F., Hung, K., \& Tse, D. K. (2008). When does guanxi matter? Issues of capitalization and its dark sides. Journal of Marketing, 72(4), 12-28.

Gujarati, D. N., \& Porter, D. C. (2009). Basic econometrics. Boston: McGraw-Hill.

Hambrick, D. C., \& Mason, P. A. (1984). Upper echelons: The organization as a reflection of its top managers. Academy of Management Review, 9(2), 193-206. Available at: https://doi.org/10.5465/amr.1984.4277628.

Haniffa, R. M., \& Cooke, T. E. (2002). Culture, corporate governance and disclosure in Malaysian corporations. Abacus, 38(3), 317-349. Available at: https://doi.org/10.1111/1467-6281.00112.

Hausman, J. A. (1978). Specification tests in econometrics. Econometrica: Journal of the Econometric Society, 46(6), 1251-1271. 
Ho, W. F., \& Yong, Y. (2017). China investments transforming Malaysia. The Star Online. Retrieved from; https://www.thestar.com.my/news/nation/2017/09/10/china-investments-transforming-msia-although-the-influxof-chinese-investments-is-only-a-recent-phen/.

Honing, S. (2012). Does diversity in executive boards make a difference? Nationality diversity and firm performance in German, Dutch and British Multinational Enterprises. Retireved from: http://ssrn.com/abstract=2147237.

Idris, A. (2008). An analysis of Malay-Sino relations in Malaysia. Asian Social Science, 4(2), 3-12.

Im, K. S., Pesaran, M. H., \& Shin, Y. (2003). Testing for unit roots in heterogeneous panels. Journal of Econometrics, 115(1), 5374. Available at: https://doi.org/10.1016/s0304-4076(03)00092-7.

Kao, C. (1999). Spurious regression and residual-based tests for cointegration in panel data. Journal of Econometrics, 90(1), 1-44.

Levin, A., Lin, C.-F., \& Chu, C.-S. J. (2002). Unit root tests in panel data: Asymptotic and finite-sample properties. Journal of Econometrics, 108(1), 1-24. Available at: https://doi.org/10.1016/s0304-4076(01)00098-7.

Mansor, I., \& Lee, S. (2016). The performance of government-linked companies in Malaysia. Capital Markets Review, 24(2), 1-13.

Marimuthu, M., \& Kolandaisamy, I. (2009). Can demographic diversity in top management team contribute for greater financial performance? An empirical discussion. The Journal of International Social Research, 2(8), 274-286.

Marimuthu., M. (2010). Bumiputera-controlled companies: performance evaluation using a non-parametric approach. International Journal of Economics and Finance, 2(2), 178-185.

Minai, M. S., Ibrahim, Y., \& Kheng, L. K. (2012). Entrepreneurial network in Malaysia: Are there any differences across ethnic groups. Journal of Business and Policy Research, 7(1), 178-192.

Morel, D. (2011). Is your management aligned with shareholders or entrenched? Fusion Investing and Analysi. Retrievd from; http://www.fusioninvesting.com/2011/04/is-your-management-aligned-with-shareholders-or-entrenched.

Narayan, P. K., Narayan, S., \& Prasad, A. (2008). A structural VAR analysis of electricity consumption and real GDP: Evidence from the G7 countries. Energy Policy, 36(7), 2765-2769. Available at: https://doi.org/10.1016/j.enpol.2008.02.027.

Nik Muhammad, N. M., \& Md Isa, F. (2009). Impact of culture and knowledge acquisition to organizational success: Study on Chinese and Malay small firms. Asian Culture and History, 1(2), 63-71.

Pedroni, P. (2004). Panel cointegration: asymptotic and finite sample properties of pooled time series tests with an application to the PPP hypothesis. Econometric Theory, 2O(3), 597-625. Available at: https://doi.org/10.1017/s0266466604203073.

Shah, B. R., Chiu, M., Amin, S., Ramani, M., Sadry, S., \& Tu, J. V. (2010). Surname lists to identify South Asian and Chinese ethnicity from secondary data in Ontario, Canada: A validation study. BMC Medical Research Methodology, 1O(1), 42-49. Available at: https://doi.org/10.1186/1471-2288-10-42.

Sheh, W. S. (2001). Chinese cultural values and their implication to Chinese management. Singapore Management Review, 23(2), 75-83.

Shleifer, A., \& Vishny, R. W. (1989). Management entrenchment: The case of manager-specific investments. Journal of Financial Economics, 25(1), 123-139.

Studenmund, A. H. (2014). Using econometrics a practical guide (6th ed.). United Kingdom: Pearson Addison-Wesley.

Tee, P. L., Lim, C. S., \& Aik, N. C. (2017). Do foreign ownership and foreign directorship matter for return on equity? Evidence from Malaysian listed companies. International Journal of Business Governance and Ethics, 12(1), 47-64. Available at: https://doi.org/10.1504/ijbge.2017.10006132.

Verbeek, M. (2008). A guide to modern econometrics (2nd ed.). Rotterdam: John Wiley \& Sons.

Williams, K. Y., \& O'Reilly III, C. A. (1998). Demography and diversity in organizations: A review of 40 years of research. Research in Organizational Behaviour, 20(1), 77-140.

Yeh, Y. h., Lee, T. s., \& Woidtke, T. (2001). Family control and corporate governance: Evidence from Taiwan. International Review of Finance, 2(1-2), 21-48.

Views and opinions expressed in this article are the views and opinions of the author(s), Asian Economic and Financial Review shall not be responsible or answerable for any loss, damage or liability etc. caused in relation to/arising out of the use of the content. 